Jurnal SOSIO DIALEKTIKA 6 (2) (2021)

P-ISSN: 2540.8941 e-ISSN: 2623.2944

e-mail; sosiodialektika@unwahas.ac.id doi; http://dx.doi.org/10.31942/sd.v6i2.5679
Efektifitas Pembelajaran Jarak Jauh Terhadap Kepuasan Proses Pembelajaran Di Prodi D3 Dan S1 Akuntansi Untidar

\title{
Efektifitas Pembelajaran Jarak Jauh Terhadap Kepuasan Proses Pembelajaran Di Prodi D3 Dan S1 Akuntansi Untidar
}

\author{
Ayunda Putri Nilasari ${ }^{1}$, Retnosari ${ }^{2}$, Supanji Setyawan ${ }^{3}$ \\ Prodi D3 Akuntansi, Fakultas Ekonomi Universitas Tidar, \\ Magelang, Indonesia \\ ayundaputri@untidar.ac.id. ${ }^{1}$ retnosari1808@untidar.ac.id $^{2}$ \\ supanji@untidar.ac.id $^{3}$
}

\begin{abstract}
The purpose of this study is to analyze how distance learning can be used to achieve student satisfaction and to analyze that the implementation of distance learning is currently effective in achieving the objectives of the teaching and learning process during the current pandemic. The population of the study was all D3 and S1 students of Accounting, Faculty of Economics, Tidar University. The samples in this study were D3 and S1 Accounting students in semesters 1, 3 and 5 who were running their lectures. This study uses a combination of qualitative and quantitative research. The data collection technique used is in the form of a questionnaire using questionnaire that given to students to get an overview of the implementation of distance learning so far. In this quantitative analysis, the research variables are arranged descriptively by assessing the percentage of standard achievement in tabular form. The results of the implementation of distance learning by lecturers already had a variation or variety and the telegram learning media was the most widely used in the percentage of $87.6 \%$. The ease of applying today's technology that makes learning media easily accessible to students is in the percentage of $55.9 \%$. The level of student understanding of learning materials, information and deepening of material by $52.4 \%$ is currently effective in achieving the objectives of the Accounting teaching and learning process during the pandemic when it is 39\%. Student satisfaction with distance learning that has been carried out during the pandemic is $40.2 \%$.
\end{abstract}

Kata kunci: distance learning, accounting, pandemic

\section{A. PENDAHULUAN}

Corona Virus Disease (Covid-19) yang melanda pada lebih dari 200 Negara termasuk Indonesia pada akhir tahun 2019 hingga kini telah banyak mempengaruhi segala aspek tak terkecuali pada aspek Pendidikan mulai dari Pendidikan Anak Usia Dini hingga pada Perguruan Tinggi. Bulan Maret 2020 semua sekolah dan kampus baik Perguruan Tinggi Negeri ataupun 
Jurnal SOSIO DIALEKTIKA 6 (2) (2021)

P-ISSN: 2540.8941 e-ISSN: 2623.2944

e-mail; sosiodialektika@unwahas.ac.id doi; http://dx.doi.org/10.31942/sd.v6i2.5679
Efektifitas Pembelajaran Jarak Jauh Terhadap Kepuasan Proses Pembelajaran Di Prodi D3 Dan S1 Akuntansi Untidar

Swasta ditutup secara serentak. Penutupan tersebut yaitu dengan tidak adanya aktivitas pembelajaran di dalam kelas, di sekolah ataupun di kampus. Pembelajaran yang awalnya dilakukan melalui tatap muka langsung, kini berganti menjadi pembelajaran jarak jauh atau pembelajaran dalam jaringan (daring).

Dalam rangka memutus rantai virus covid -19, Pemerintah Indonesia melalui Kementerian Pendidikan dan Kebudayaan (Kemendikbud) menerbitkan Surat Edaran Nomor 4 Tahun 2020 tentang Pelaksanaan Pendidikan Dalam Masa Darurat Corona virus Disease (Covid-19) yaitu menerapkan kebijakan belajar dan bekerja dari rumah mulai pertengahan Maret 2020. Universitas Tidar sebagai salah satu Perguruan Tinggi Negeri di bawah Kementerian Pendidikan dan Kebudayan, melalui Surat Edaran Rektor Nomor: 4/UN57/SE/TU/2020 Tentang Pelaksanaan Pembelajaran Secara Daring dan Bekerja Dari Rumah Dalam Rangka Pencegahan Penyebaran Corona Virus Disease (Covid-19) Di Lingkungan Universitas Tidar yaitu menerapkan kebijakan proses pembelajaran dari tatap muka langsung berganti menjadi dalam jaringan (daring). Pergantian sistem pembelajara tersebut tentunya mempunyai dampak terhadap mahasiswa itu sendiri. Mahasiswa yang tadinya menerima materi di dalam kelas dengan penjelasan langsung oleh Dosen kini belajar mandiri dari rumah. Hal tersebut merupakan tantangan bagi mahasiswa tertentu.

Pendidikan atau pembelajaran jarak jauh di masa pandemi Covid-19 merupakan salah satu solusi yang diambil guna mengatasi permasalah pendidikan. Istilah pendidikan jarak jauh (PJJ) sudah lama diterapkan oleh para dosen/pendidik maupun mahasiswa/peserta didik pada saat proses pembelajarannya dilakukan secara terpisah di luar kelas. Secara terpisah disini antara pendidik/narasumber dan peserta didik/pelatihan tidak dalam satu ruangan yang sama (tidak terjadi tatap muka secara langsung) bahkan waktunya bisa berbeda. Interaksi dosen/narasumber dan mahasiswa/peserta pelatihan dilakukan secara langsung maupun tidak langsung, misal dengan chatting melalui internet atau media komunikasi (langsung) maupun dengan 
Jurnal SOSIO DIALEKTIKA 6 (2) (2021)

P-ISSN: 2540.8941 e-ISSN: 2623.2944

e-mail; sosiodialektika@unwahas.ac.id doi; http://dx.doi.org/10.31942/sd.v6i2.5679
Efektifitas Pembelajaran Jarak Jauh Terhadap Kepuasan Proses Pembelajaran Di Prodi D3 Dan S1 Akuntansi Untidar

berkirim email untuk pengumpulkan tugas (Rahmawati, 2016).

Dalam pengembangannya, saat ini sudah banyak bermunculan aplikasi sebagai media yang mempermudah proses pembelajaran jarak jauh diantaranya Whatsapp Group, Telegram, Zoom, Google meeting, dan lain sebagainya. Kegiatan diskusi, share materi dan interaksi pembelajaran dapat dilakukan melalui aplikasi tersebut dalam segala mata kuliah di program studi Akuntansi S1 dan D3 Fakultas Ekonomi. Dalam pelaksanaannya pembelajaran daring sudah dilakukan mulai semester genap 2019/2020 hingga semester gasal 2020/2021. Evaluasi pembelajaran akuntansi baik UTS/UAS juga dilakukan melalui daring. Oleh karena itu, peneliti ingin mengetahui respon dari mahasiswa selama pembelajaran daring dilihat dari kepuasan dan efektifitas dalam proses kegiatan belajar mengajar selama masa pandemi Covid-19 guna membantu pengambil kebijakan dalam menentukan keputusan untuk semester berikutnya jika pembelajaran masih berbasis daring.

Pembelajaran daring merupakan pembelajaran yang menggunakan model interaktif berbasis internet dan Learning Manajemen System (LMS). Mata kuliah daring dikembangkan berdasarkan dokumen perencanaan proses pembelajaran yang menyangkut: a) Rancangan pengalaman belajar; b) Komposisi belajar (mandiri dan terbimbing); c) Strategi belajar; d) Panduan Pelaksanaan pembelajaran; e) Peta Program yang merupakan panduan untuk mengembangkan bahan ajar daring; f) Bahan Ajar yang sudah harus tersedia sebelum mata kuliah dijalankan secara daring

Media yang digunakan dalam membantu memudahkan PJJ pada dasarnya dipengaruhi oleh pekembangan IPTEK. Dalam era perkembangan teknologi yang semakin pesat, media yang dapat dipilih dan digunakan semakin beragam. Media merupakan alat komunikasi yang digunakan untuk menyampaikan suatu informasi. Apabila media ini dikaitkan dengan kegiatan pembelajaran, maka dapat diartikan bahwa media adalah alat komunikasi yang digunakan untuk membawa informasi yang dimaksudkan untuk pembelajaran (Smaldino et al., 2014). Semakin banyaknya ragam 
Jurnal SOSIO DIALEKTIKA 6 (2) (2021)

P-ISSN: 2540.8941 e-ISSN: 2623.2944

e-mail; sosiodialektika@unwahas.ac.id doi; http://dx.doi.org/10.31942/sd.v6i2.5679
Efektifitas Pembelajaran Jarak Jauh Terhadap Kepuasan Proses Pembelajaran Di Prodi D3 Dan S1 Akuntansi Untidar

media yang dapat digunakan dalam proses pembelajaran, maka untuk memudahkan mempelajari media-media tersebut pada umumnya dilakukan pengelompokan. Media dan kemudahan akses yang digunakan oleh dosen dalam proses pembelajaran guna penyampaian materi ajar berperan penting diperkuliahan (Restrepo et al., 2012). Pengelompokan media dalam PJJ berdasarkan bentuk fisik yang yang terlihat, dan membaginya dalam empat klasifikasi yaitu media cetak, media audio-visual, media praktikum dan media interaktif (Sanjaya, 2015).

Dengan IPTEK dan jaringan internet yang semakin berkembang, disertai pemanfaatan gadget, laptop maupun komputer dalam sistem PJJ menjadikan proses belajar lebih luas dan fleksibel. Beberapa media saat ini yang banyak digunakan seperti Whatsapp, Telegram, Youtube, Zoom dan Google Meeting/Google Classroom. Melalui YouTube proses belajar mengajar online lebih praktis hanya dengan menyisipkan URL video di situs YouTube yang akan dipilih. Pengguna dapat meng account untuk di tampilkan di depan kelas YouTube menawarkan alternative sumber pendidikan yang tepat waktu, namun memilki tantangan yang unik yaitu keterbatasan ketersediaan dari video tersebut. Mengintegrasikan video YouTube memungkinkan peserta didik lebih kreatif dalam belajar dan tidak terbatas hanya dalam materi pelajaran. Video YouTube benar-benar memberikan kejelasan kepada peserta didik untuk melihat gambaran visual dari berbagai kondisi dan juga memberikan kesempatan bagi peserta didik untuk benar-benar melihat kondisi yang sebenarnya.

Salah satu misi dari Fakultas Ekonomi Universitas Tidar adalah Menyelenggarakan pendidikan dalam bidang ekonomi yang berkualitas dan unggul. (visi dan misi Fakultas Ekonomi https://fe.untidar.ac.id/, diakses 9 November 2020). Dalam misi tersebut tentu tersirat penyelenggaraan pendidikan yang terbaik dalam rangka mencapai visi. Dimasa pandemi Covid-19 Universitas Tidar mulai meningkatkan penggunaan IPTEK dengan E-Learning elita.untidar.ac.id dengan proses media pembelajaran yang berbagai platform sesuai kesepakatan dosen dengan mahasiswa. Tentu 
Jurnal SOSIO DIALEKTIKA 6 (2) (2021)

P-ISSN: 2540.8941 e-ISSN: 2623.2944

e-mail; sosiodialektika@unwahas.ac.id doi; http://dx.doi.org/10.31942/sd.v6i2.5679
Efektifitas Pembelajaran Jarak Jauh Terhadap Kepuasan Proses Pembelajaran Di Prodi D3 Dan S1 Akuntansi Untidar

saja dalam upaya pencapaian visi tersebut, fakultas harus berbenah dan meningkatkan proses PJJ guna memberikan layanan pendidikan terbaik. Terbaik dalam arti dapat memuaskan mahasiswa sebagai calon SDM berkualitas yang menjadi tolok ukur keberhasilan sebuah institusi pendidikan di perguruan tinggi.

Banyak faktor yang memengaruhi kepuasan PJJ diantaranya: teknologi, konten edukasi, motivasi dan sikap (Jafari Navimipour \& Zareie, 2015), tingkat kesiapan mahasiswa (YILMAZ et al., 2017), kesesuaian informasi dengan kebutuhan (Isaac et al., 2019), desain pembelajaran (Rienties \& Toetenel, 2016), kualitas informasi (Pereira et al., 2015), pengalaman (Deshwal et al., 2017). Jika mahasiswa memperoleh kepuasan pembelajaran online maka akan berpengaruh terhadap motivasi dan hasil pembelajaran (Wang et al., 2019), nilai yang dipersepsikan dan intensitas keberlanjutan (Nugroho et al., 2019). Kepuasan mahasiswa dalam menjalani PJJ ini menjadi masukan penting dalam rangka perbaikan di masa yang mendatang. Peranan literasi teknologi informasi dan komunikasi penting dalam PJJ di masa pandemi Covid-19 ini (Latip, 2020). Terutama jika pandemi Covid-19 masih terjadi maka PJJ akan terus dipilih sebagai metode paling aman terutama di Kota Magelang dimana lokasi perguruan tinggi berada yang sampai saat ini berada pada zona merah.

Penelitian ini dapat berkontribusi dalam memberikan masukan terkait pelaksanaan PJJ saat ini. Oleh karena itu, tujuan penelitian ini adalah untuk mengetahui dampak pandemic Covid-19 terhadap kepuasan pembelajaran jarak jauh dengan indikator kepuasan yang akan diteliti meliputi= a) Teknologi; b) Motivasi; c) Kualitas Informasi; d) Desain Pembelajaran; dan e) Hasil Pembelajaran

Teknologi dalam penggunaan media pembelajaran apakah sesuai dengan kemampuan sumber daya manusia dan sumber daya modal yang tersedia. Pembelajaran jarak jauh ini apakah menimbulkan motivasi mahasiswa untuk terus mengikuti perkuliahan secara aktif dan semangat dalam belajar. Selain itu informasi yang diberikan selama proses 
Jurnal SOSIO DIALEKTIKA 6 (2) (2021)

P-ISSN: 2540.8941 e-ISSN: 2623.2944

e-mail; sosiodialektika@unwahas.ac.id doi; http://dx.doi.org/10.31942/sd.v6i2.5679
Efektifitas Pembelajaran Jarak Jauh Terhadap Kepuasan Proses Pembelajaran Di Prodi D3 Dan S1 Akuntansi Untidar

pembelajaran jarak jauh apakah sesuai dengan kontrak kuliah dan Rencana Pembelajaran Semester yang diawal pertemuan sudah diinformasikan, serta kualitas materi sesuai dengan kebutuhan mahasiswa meski dalam pelaksanaanya menggunakan fasilitas media jarak jauh. Desain pembelajaran yang menarik oleh pengajar/pendidik akan memberi kepuasan kepada mahasiswa sehingga mereka dapat mudah memahami materi dan tidak merasa bosan. Tujuan dari proses belajar mengajar selain mahasiswa memahami materi, namun harapannya mahasiswa mendapat hasil yang maksimal sehingga mahasiswa memperoleh kepuasan atas pembelajaran yang selama ini dilakukan.

Efektivitas secara umum menunjukan sampai seberapa jauh tercapainya suatu tujuan yang terlebih dahulu ditentukan. Hal tersebut sesuai dengan pengertian efetivitas adalah suatu ukuran yang menyatakan seberapa jauh target (kuantitas, kualitas dan waktu) telah tercapai, atau maka besar presentase target yang dicapai, makin tinggi efektivitasnya (Veronica \& Jaya, 2018). Pada kegiatan mengajar terkandung kemampuan menganalisis kebutuhan siswa, mengambil putusan apa yang harus dilakukan, merancang pembelajaran yang efektif dan efisien, mengaktifkan siswa melalui motifasi eksrinstik dan intrinsik, mengevaluasi hasil belajar, serta merevisi pembelajaran berikutnya agar lebih efektif guna meningkatkan prestasi belajar siswa. Pengertian efektivitas tersebut dapat disimpulkan bahwa efektivitas merupakan suatu ukuran ang menyatakan seberapa jauh target (kuantias, kualitas dan waktu) yang telah tercapai oleh manajmen,yang mana target tersebut sudah ditentukan terlebih dahulu. Efektivitas pembelajaran jarak jauh menggunakan media online selama pandemic Covid-19 dapat dilakukan dengan penyampaian ringkasan materi dalam bentuk video yang mudah dipahami, penugasan dan soal bervariatif dengan instruksi yang jelas (Mustakim, 2020). Hal ini sejalan dalam tujuan pembelajaran yang telah ditetapkan dapat dicapai dengan capaian kuantitas, kualitas dan waktu. Dalam konteks kegiatan pembelajaran perlu dipertimbangkan efektivitas artinya sejauhmana tujuan yang telah 
Jurnal SOSIO DIALEKTIKA 6 (2) (2021)

P-ISSN: 2540.8941 e-ISSN: 2623.2944

e-mail; sosiodialektika@unwahas.ac.id doi; http://dx.doi.org/10.31942/sd.v6i2.5679
Efektifitas Pembelajaran Jarak Jauh Terhadap Kepuasan Proses Pembelajaran Di Prodi D3 Dan S1 Akuntansi Untidar

ditetapkan dapat dicapai sesuai harapan.

Indikator efektifitas yang akan dianalisis dalam penelitian ini meliputi:

a) Kuantitas pertemuan proses pembelajaran yang sesuai dengan aturan kampus, b) Kualitas materi/informasi yang disampaikan sesuai dengan kebutuhan mahasiswa dan kurikulum, dan c) Pelaksanaan pembelajaran jarak jauh sesuai dengan waktu KBM. Hasil analisis efektifitas pembelajaran jarak jauh selama ini nantinya dapat membantu pengambil kebijakan dalam menentukan arah disemester berikutnya jika masih dalam masa pandemi. Tujuan yang hendak dicapai dalam penelitian ini adalah sebagai berikut:

1. Mengetahui dan menganalisis apakah pembelajaran jarak jauh (daring) dapat digunakan untuk mencapai kepuasan dalam proses kegiatan belajar mengajar di masa pandemi Covid-19 saat ini.

2. Mengetahui dan menganalisis apakah pelaksanaan pembelajaran jarak jauh (daring) saat ini sudah efektif dalam mencapai tujuan proses kegiatan belajar mengajar di masa pandemi Covid-19 saat ini.

Rumusan masalah dalam penelitian ini adalah:

1. Apakah pembelajaran jarak jauh (daring) dapat digunakan untuk mencapai kepuasan dalam proses kegiatan belajar mengajar Prodi Akuntansi Untidar di masa pandemi Covid-19 saat ini?

2. Apakah pelaksanaan pembelajaran jarak jauh (daring) saat ini sudah efektif dalam mencapai tujuan proses kegiatan belajar mengajar Prodi Akuntansi Untidar di masa pandemi Covid-19 saat ini?

\section{B. METODE PENELITIAN}

\section{Populasi dan Sampel}

Populasi dari penelitian ini adalah seluruh mahasiswa D3 dan S1 Akuntansi Fakultas Ekonomi Untidar. Sampel dalam penelitian ini yaitu mahasiswa jurusan Akuntansi yang terdiri dari D3 dan S1 Akuntansi semester 1, 3 dan 5 yang sedang menjalankan masa perkuliahan. Sampel menggunakan mahasiswa akuntansi dikarenakan peneliti ingin mengetahui 
Jurnal SOSIO DIALEKTIKA 6 (2) (2021)

P-ISSN: 2540.8941 e-ISSN: 2623.2944

e-mail; sosiodialektika@unwahas.ac.id doi; http://dx.doi.org/10.31942/sd.v6i2.5679
Efektifitas Pembelajaran Jarak Jauh Terhadap Kepuasan Proses Pembelajaran Di Prodi D3 Dan S1 Akuntansi Untidar

bagaimana efektivitas dari pembelajaran jarak jauh bila diterapkan pada mata kuliah -mata kuliah yang lebih banyak memerlukan perhitungan daripada teori.

\section{Jenis Penelitian dan Teknik Pengumpulan Data}

Penelitian ini menggunakan jenis penelitian kombinasi (mixed methods) kualitatif dan kuantitatif. Metode penelitian kombinasi adalah suatu metode penelitian yang mengkombinasikan atau menggabungkan antara metode kuantitatif dan metode kualitatif untuk digunakan secara bersama-sama dalam suatu kegiatan penelitian, sehingga diperoleh data yang lebih komprehensif, valid, reliabel dan obyektif. Melalui kombinasi dua metode, maka data yang diperoleh dari penelitian akan lebih valid, karena data yang kebenarannya tidak dapat divalidasi dengan metode kuantitatif akan divalidasi dengan metode kualitatif atau sebaliknya (Sugiyono, 2018).

Didasari permasalahan yang akan diteliti yaitu menganalisis efektivitas pembelajaran jarak jauh terhadap kepuasan proses pembelajaran pada mahasiswa Fakultas Ekonomi Untidar maka penelitian ini menggunakan jenis penelitian kombinasi kuantitatif kualitatif. Penelitian kuantitatif dilakukan untuk melihat tingkat efektivitas belajar mahasiswa penelitian kualitatif untuk mengetahui respon mahasiswa terhadap pelaksanaan belajar jarak jauh. Hal ini dilakukan secara sepadan, tidak terlalu dominan pada salah satunya.

Teknik pengumpulan data yang digunakan adalah kuisioner menggunakan angket yang diberikan kepada mahasiswa untuk mendapatkan gambaran pelaksanaan pembelajaran jarak jauh selama ini. Dalam analisis kuantitatif ini variabel penelitian disusun secara deskriptif dengan menilai prosentase pencapaian standar dalam bentuk tabel. Teknik analisis data yang digunakan adalah milik Miles and Huberman. Miles and Huberman (Sugiyono, 2018) mengemukakan bahwa aktivitas dalam analisis data kualitatif dilakukan secara interaktif dan berlangsung secara terus menerus sampai tuntas, sehingga datanya sudah jenuh. Aktivitas dalam analisis data, 
Jurnal SOSIO DIALEKTIKA 6 (2) (2021)

P-ISSN: 2540.8941 e-ISSN: 2623.2944

e-mail; sosiodialektika@unwahas.ac.id doi; http://dx.doi.org/10.31942/sd.v6i2.5679
Efektifitas Pembelajaran Jarak Jauh Terhadap Kepuasan Proses Pembelajaran Di Prodi D3 Dan S1 Akuntansi Untidar

yaitu: data reduction, data display, conclusion drawing/verification.

Data yang diperoleh disajikan dalam bentuk tabel dan dideskripsikan. Pendeskripsian data dilakukan dalam bentuk persen.

$$
\%=\frac{\text { jumlahbagian }}{\text { jumlahkeseluruhan }} \times 100 \%
$$

Perhitungan nilai rata-rata dilakukan dengan menjumlahkan seluruh nilai data suatu kelompok sampel, kemudian dibagi dengan jumlah sampel tersebut. Jadi jika suatu kelompok sampel acak denga jumlah sampel n, maka dapat dihitung rata-rata dari sampel tersebut sebagai berikut.

$$
\chi=\sum_{i=1}^{n} x_{1}
$$

\section{HASIL DAN PEMBAHASAN}

Penelitian dilaksanakan kepada mahasiswa jurusan akuntansi S1 dan D3 Fakultas Ekonomi Untidar Angkatan 2020 dan 2019 tahun ajaran genap 2020/2021 yang sedang menjalankan pembelajaran daring dengan jumlah mahasiswa yang menjadi responden sebanyak 378 mahasiswa. Dari jumlah tersebut sebanyak 96 mahasiswa D3 Akuntansi dan 282 mahasiswa S1 Akuntansi yang telah mengisi kuesioner. Kuesioner yang dibagikan berisi 16 pertanyaan, diantara angket ada yang menggunakan pertanyaan terbuka dan ada yang menggunakan skala Likert. Sewaktu menanggapi pertanyaan dalam skala Likert, responden menentukan tingkat persetujuan mereka terhadap suatu pernyataan dengan memilih salah satu dari pilihan yang tersedia. Lima pilihan skala dengan format seperti ini:

1) Sangat tidak setuju, 2) Tidak setuju, 3) kurang setuju, 4) Setuju, dan 5) Sangat setuju

Adapun kisi-kisi pertanyaan di dalam kuesioner meliputi: 
Jurnal SOSIO DIALEKTIKA 6 (2) (2021)

P-ISSN: 2540.8941 e-ISSN: 2623.2944

e-mail; sosiodialektika@unwahas.ac.id doi; http://dx.doi.org/10.31942/sd.v6i2.5679
Efektifitas Pembelajaran Jarak Jauh Terhadap Kepuasan Proses Pembelajaran Di Prodi D3 Dan S1 Akuntansi Untidar

Tabel 2 Kisi-kisi Angket Respon Mahasiswa Terhadap PJJ

\begin{tabular}{clcc}
\hline No & \multicolumn{1}{c}{ Indikator } & Item Pertanyaan & No Butir Soal \\
\hline 1 & Teknologi & 2 & 1,2 \\
\hline 2 & Motivasi & 1 & 3 \\
\hline 3 & Kualitas Informasi & 2 & 4,5 \\
\hline 4 & Desain Pembelajaran & 1 & 6 \\
\hline 5 & Hasil Pembelajaran & 2 & 7,8 \\
\hline 6 & Efektivitas PJJ & 1 & 9 \\
\hline 7 & Kuantitas Pertemuan & 2 & 10,11 \\
\hline 8 & Kualitas Materi, Media, PJJ & 3 & $12,13,14$ \\
\hline 9 & Pemenuhan Waktu PJJ & 2 & 15,16 \\
\hline & & &
\end{tabular}

Hasil dari angket yang telah disebar kepada responden didapatkan bahwa pembelajaran jarak jauh yang dosen/pendidik gunakan untuk kegiatan belajar menggunakan media pembelajaran online selama masa pandemi di FE untidar yang banyak dimanfaatkan adalah Telegram group, Zoom, Whatsapp group serta ada beberapa aplikasi lainnya seperti google classroom, youtube dan video offline. Dalam keadaan sebenarnya ada beberapa dosen yang menggunakan lebih dari satu media pembelajaran atau melakukan mix media dalam satu mata kuliah. Hal tersebut dilakukan untuk mengupayakan efektivitas dari pelaksanaan pembelajaran daring yang dilakukan oleh dosen. Penggunaan media pembelajaran jarak jauh yang digunakan sesuai dengan penerapan teknologi dan membantu memudahkan proses pembelajaran selama pandemi Covid-19 mahasiswa sebesar sebesar $55,9 \%$. Penggunaan media pembelajaran oleh dosen selama pandemi Covid19 dapat memotivasi mahasiswa untuk terus dan semangat belajar serta mengikuti perkuliahan dipertemuan selanjutnya sebesar 39,3\%.

Selama pembelajaran jarak jauh yang sudah dilakukan oleh dosen, materi dan informasi serta pendalaman materi atau penugasan yang disampaikan selama proses pembelajaran jarak jauh dapat dipahami dan dimengerti dengan baik oleh mahasiswa sebesar 52,4\%. Hal tersebut juga 
Jurnal SOSIO DIALEKTIKA 6 (2) (2021)

P-ISSN: 2540.8941 e-ISSN: 2623.2944

e-mail; sosiodialektika@unwahas.ac.id doi; http://dx.doi.org/10.31942/sd.v6i2.5679
Efektifitas Pembelajaran Jarak Jauh Terhadap Kepuasan Proses Pembelajaran Di Prodi D3 Dan S1 Akuntansi Untidar

tidaklah lepas dari keterkaitan materi dan informasi pembelajaran jarak jauh yang sudah dilakukan dosen sesuai dengan kontrak kuliah dan rencana pembelajaran semester yang telah disampaikan atau mencapai 63,9\%. Dosen dalam memberikan materi pembelajaran telah mencapai kesesuaian dengan tujuan pembelajaran dan kebijakan dari universitas atau sebesar 67,3\%. Dalam memberikan pendalaman materi/penugasan selama proses pembelajaran jarak jauh telah memberikan kepuasan sebesar $38,4 \%$ bagi mahasiswa dengan hasil belajar yang memuaskan sebesar $40,2 \%$. Prosentase mahasiswa bisa mengikuti proses pembelajaran jarak jauh dengan baik sebesar 55,2\% dengan rata-rata mahasiswa belajar dari rumah dalam satu hari selama 4-6 jam.

Pembelajaran jarak jauh tidak selalu berjalan tanpa adanya hambatanhambatan. Hambatan yang dihadapi mahasiswa saat proses pembelajaran jarak jauh selama pandemi jawaban terbanyak kesulitan memahami, kurang konsentrasi, jaringan internet yang kurang stabil dan bosan. Dalam menjembatani hambatan upaya atau dukungan dari kampus selalu dilakukan yaitu diantaranya memberikan paket data, menyediakan akses dan peminjaman buku online bagi mahasiswa. Hal tersebut dilakukan untuk agar pembelajaran jarak jauh dapat berjalan dengan baik dan efektif.

Penelitian ini menghasilkan poin-poin penting terkait respon dari mahasiswa selama pembelajaran daring dilihat dari kepuasan dan efektifitas dalam proses kegiatan belajar mengajar selama masa pandemi Covid-19 guna membantu pengambil kebijakan dalam menentukan keputusan untuk semester berikutnya jika pembelajaran akuntansi masih berbasis daring. Hasil penelitian dipaparkan mulai dari media pembelajaran yang digunakan dan kepuasan terhadap pembelajaran akuntansi selengkapnya dipaparkan sebagai berikut.

\section{Media Pembelajaran}

Media yang digunakan oleh dosen untuk menyampaikan materi dalam proses pembelajaran akuntansi menjadikan mahasiswa mampu menyerap materi yang disampaikan sesuai dengan tujuan pembelajaran. Banyak media 
Jurnal SOSIO DIALEKTIKA 6 (2) (2021)

P-ISSN: 2540.8941 e-ISSN: 2623.2944

e-mail; sosiodialektika@unwahas.ac.id doi; http://dx.doi.org/10.31942/sd.v6i2.5679
Efektifitas Pembelajaran Jarak Jauh Terhadap Kepuasan Proses Pembelajaran Di Prodi D3 Dan S1 Akuntansi Untidar

yang digunakan dosen diantaranya

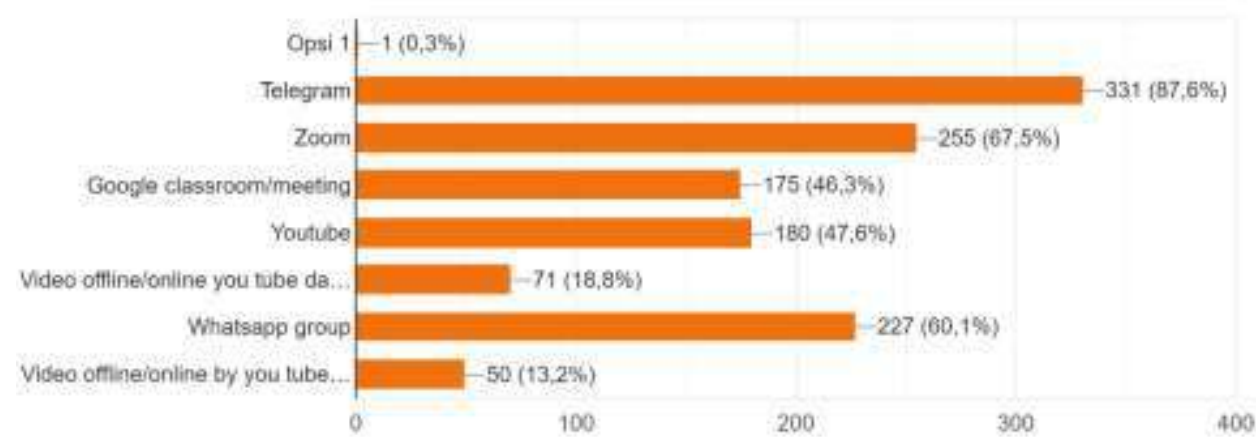

Gambar 1 Media Yang Digunakan Dalam Proses Pembelajaran

Akuntansi

Dari diagram di atas Telegram 87,6\% media yang paling banyak digunakan. Banyak fitur yang disediakan oleh telegram group untuk media penyampaian informasi yang mampu menampung anggota 1 group bisa sampai 200.000 orang dan terdapat polling yang dibisa digunakan untuk absensi maupun kuis. Media yang kedua banyak digunakan adalah zoom $67,5 \%$ dimana dosen dan mahasiswa dapat bertatapmuka secara virtual untuk menyampaikan materi dengan share screen baik materi dalam bentuk power poin, video, word maupun lainnya. Media yang ketiga Whatsapp $60,1 \%$ untuk komunikasi materi maupun pengumpulan tugas. Di Universitas Tidar bagi mahasiswa maupun dosen dapat mengakses Elita dengan alamat elita.untidar.ac.id untuk kepentingan perkuliahan baik untuk presensi kehadiran, distribusi materi, pengumpulan tugas, distribusi soal ujian, pengumpulan lembar jawab ujian, dan lain sebagainya. Dalam praktiknya di Fakultas Ekonomi penggunaan mix media atau menggunakan beberapa media pembelajaran selama masa pandemi telah dilakukan oleh beberapa dosen dalam satu mata kuliah dengan elita sebagai media pembelajaran utama atau wajib digunakan sesuai dengan ketentuan dari Universitas. Mix media yang telah dilakukan diharapkan dapat meningkatan motivasi belajar mahasiswa dimana efektivitas pembelajaran jarak jauh yang jadi tujuan utamanya.

Semakin meningkat penerapan teknologi yang digunakan, semakin beraneka ragam media pembelajaran akuntansi yang digunakan dalam 
Jurnal SOSIO DIALEKTIKA 6 (2) (2021)

P-ISSN: 2540.8941 e-ISSN: 2623.2944

e-mail; sosiodialektika@unwahas.ac.id doi; http://dx.doi.org/10.31942/sd.v6i2.5679
Efektifitas Pembelajaran Jarak Jauh Terhadap Kepuasan Proses Pembelajaran Di Prodi D3 Dan S1 Akuntansi Untidar

membantu memudahkan proses KBM selama pandemic Covid-19 yang dapat dilihat pada chart di bawah ini.

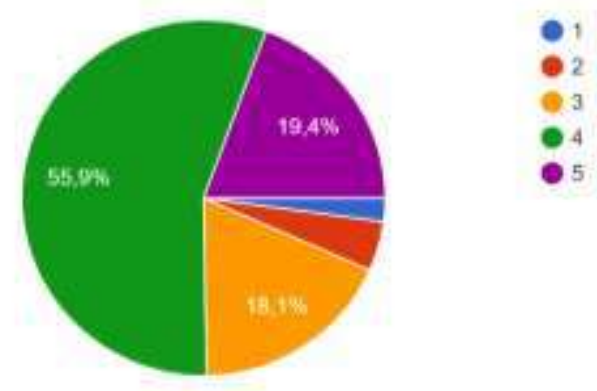

\section{Gambar 2 Diagram Penerapan Teknologi Memudahkan Proses Pembelajaran Selama Pandemi Covid-19}

Kemudahan penerapan teknologi masa kini menjadikan media pembelajaran mudah diakses mahasiswa sebesar 55,9\% setuju, 19,4\% sangat setuju dan $18,1 \%$ biasa. Mahasiswa yang memiliki kemampuan menggunakan internet menjadikan mereka mudah mencari materi dan mengakses materi dari dosen. Semakin menarik media yang digunakan akan menjadikan mahasiswa tertarik mempelajarinya dan materi yang

disampaikan dapat terserap dengan baik. Hal ini sejalan dengan dengan hasil penelitian yang menjelaskan media dan kemudahan akses yang digunakan oleh dosen dalam proses pembelajaran guna penyampaian materi ajar berperan penting diperkuliahan (Restrepo et al., 2012). Dari interaksi melalui media ini diharapkan materi, informasi dan pendalaman materi/penugasan mata kuliah akuntansi yang disampaikan selama proses PJJ dapat dipahami dan dimengerti dengan baik oleh mahasiswa yang disajikan pada diagram di bawah ini.
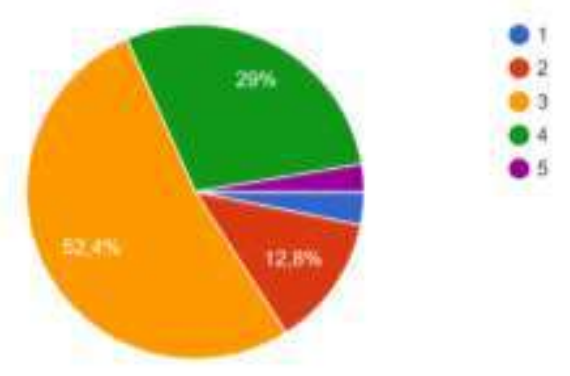

Gambar 3 Diagram Pemahaman Mahasiswa Terhadap Materi, Informasi dan Pendalaman Materi 
Jurnal SOSIO DIALEKTIKA 6 (2) (2021)

P-ISSN: 2540.8941 e-ISSN: 2623.2944

e-mail; sosiodialektika@unwahas.ac.id doi; http://dx.doi.org/10.31942/sd.v6i2.5679
Efektifitas Pembelajaran Jarak Jauh Terhadap Kepuasan Proses Pembelajaran Di Prodi D3 Dan S1 Akuntansi Untidar

Proses pembelajaran jarak jauh selama pandemic yang telah berlangsung untuk tingkat pemahaman mahasiswa akuntansi 52,4\% biasa, $29 \%$ setuju dan $12,8 \%$ tidak setuju. Hal ini dapat terjadi berdasarkan hasil penelitian karena beberapa hambatan yang mahasiswa alami selama proses pembelajaran jarak jauh di masa pandemic diantaranya: 1) kesulitan memahami materi karena biasanya bertatap muka secara langsung di ruang kelas namun selama pandemic mereka bertatap muka melalui virtual; 2) Kurang konsentrasi karena jika di rumah mereka ada beberapa gangguan kecil sehingga tidak focus; 3) Jaringan internet kurang stabil dikarena masalah teknis; dan 4) Bosan dimana rata-rata mahasiswa belajar dari rumah dalam satu hari selama 4-6 jam. Guna mengatasi hambatan tersebut, dukungan kampus Universitas Tidar yang telah diberikan selama proses pembelajaran jarak jauh di masa pandemic diantaranya:1) Memberikan paket data, 2) Menyediakan akses aplikasi belajar daring secara gratis melalui elita dan 3) Meminjamkan buku secara online.

\section{Kepuasan Pembelajaran Jarak Jauh}

Kepuasan mahasiswa dalam menjalani PJJ ini menjadi masukan penting dalam rangka perbaikan di masa yang mendatang. Peranan literasi teknologi informasi dan komunikasi penting dalam PJJ di masa pandemi Covid-19 ini (Latip, 2020). Terutama jika pandemi Covid-19 masih terjadi maka PJJ akan terus dipilih sebagai metode paling aman terutama di Kota Magelang dimana lokasi perguruan tinggi Universitas Tidar berada yang sampai saat ini berada pada zona merah. Selama pembelajaran jarak jauh di masa pandemic, mahasiswa memperoleh hasil belajar yang memuaskan disajikan di bawah ini. 
Jurnal SOSIO DIALEKTIKA 6 (2) (2021)

P-ISSN: 2540.8941 e-ISSN: 2623.2944

e-mail; sosiodialektika@unwahas.ac.id doi; http://dx.doi.org/10.31942/sd.v6i2.5679
Efektifitas Pembelajaran Jarak Jauh Terhadap Kepuasan Proses Pembelajaran Di Prodi D3 Dan S1 Akuntansi Untidar

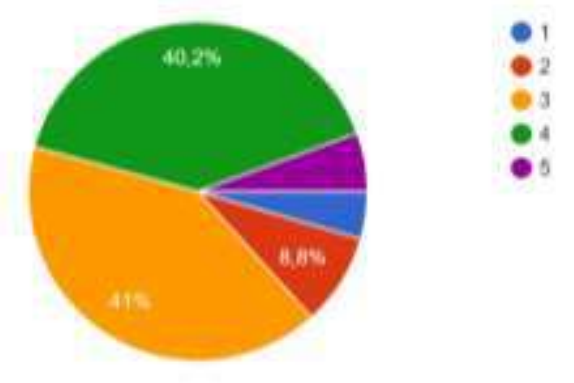

\section{Gambar 4 Kepuasan Terhadap Hasil Belajar Selama Pembelajaran Jarak Jauh di Masa Pandemi}

Kepuasan yang dialami mahasiswa Akuntansi terhadap pembelajaran jarak jauh selama pandemic $41 \%$ biasa, 40,2 setuju dan $8,8 \%$ tidak setuju. Pada proses pembelajaran jarak jauh memang banyak materi ajar akuntansi yang disampaikan melalui media telegram, zoom, whatsapp dan lain sebagainya yang bertujuan untuk meningkatkan pemahaman dan berpikir kritis mahasiswa. Namun mahasiswa menganggap tugas yang diberikan dosen tes penilaian hasil belajar dimana mahasiswa merasa berat dalam mengerjakannya. Tugas dan pendalaman yang diberikan dosen adalah sebuah proses pembelajaran, bukan untuk menilai hasil akhir saja. Dalam hal ini ada perbedaan pemahaman dari mahasiswa dan dosen terhadap proses penilaian/evaluasi.

Perbedaan pemahaman itu disebabkan dari ketidakefektifan proses belajar dari rumah dikarenakan hambatan yang telah peneliti analisis pada paragraph sebelumnya. Banyak gangguan (distruction) Ketika mahasiswa belajar dari rumah seperti game/TV/film drama korea yang menjadikan mahasiswa tergoda atau kurang focus saat menerima materi. Mahasiswa cenderung terbagi perhatian berpikirnya dan ingin cepat selesai. Kurangnya komunikasi yang efektif yang kurang dimanfaatkan oleh mahasiswa dosen dalam kesempatan proses belajar jarak jauh sehingga jika ada materi yang kurang dipahami mereka enggan bertanya dan lama kelamaan menjadi membosankan bagi mahasiswa. Selain itu kendala sinyal yang jelek di daerah tempat tinggal atau pada saat cuaca buruk yang membuat 
Jurnal SOSIO DIALEKTIKA 6 (2) (2021)

P-ISSN: 2540.8941 e-ISSN: 2623.2944

e-mail; sosiodialektika@unwahas.ac.id doi; http://dx.doi.org/10.31942/sd.v6i2.5679
Efektifitas Pembelajaran Jarak Jauh Terhadap Kepuasan Proses Pembelajaran Di Prodi D3 Dan S1 Akuntansi Untidar

penyampaian informasi tersendat dan kurang lancar.

\section{Efektifitas pembelajaran jarak jauh}

Kondisi PSBB dan PPKM darurat yang menjadikan kegiatan belajar dari rumah untuk mengurasi kerumuman dan interaksi ini menjadikan pembelajaran jarak jauh menjadi salah satu alternatif di dunia Pendidikan. Berdasarkan hasil kuisioner yang diisi mahasiswa akuntansi terhadap efektifitas pembelajaran jarak jauh di masa pandemic disajikan diagram di bawah ini.
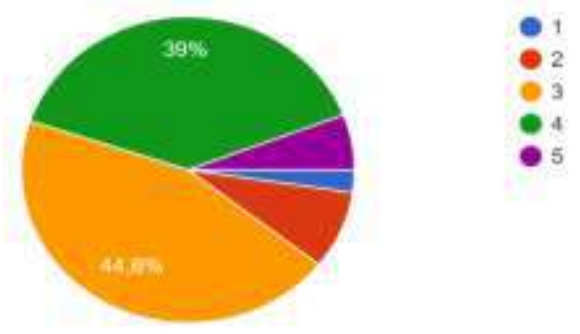

\section{Gambar 5 Diagram Efektifitas Pembelajaran Jarak Jauh Selama Pandemi Covid-19}

Secara keseluruhan 44,6\% menjawab biasa dan 39\% menjawab setuju efektif. Keefektifan dari sisi mahasiswa ini dirasa karena mereka berpikir dengan penyampaian materi melalui media online adalah salah satu alternatif pembelajaran selama pandemic. Efektivitas pembelajaran jarak jauh menggunakan media online selama pandemic Covid-19 dapat dilakukan dengan penyampaian ringkasan materi dalam bentuk video yang mudah dipahami, penugasan dan soal bervariatif dengan instruksi yang jelas (Mustakim, 2020). Hal ini sejalan dalam tujuan pembelajaran yang telah ditetapkan dapat dicapai dengan capaian kuantitas, kualitas dan waktu. Dalam konteks kegiatan pembelajaran perlu dipertimbangkan efektivitas artinya sejauhmana tujuan yang telah ditetapkan dapat dicapai sesuai harapan.

\section{SIMPULAN DAN SARAN}

Selama pandemic Covid-19 saat ini yang membawa banyak dampak di duni Pendidikan menjadikan pelaksanaan pembelajaran jarak jauh yang 
Jurnal SOSIO DIALEKTIKA 6 (2) (2021)

P-ISSN: 2540.8941 e-ISSN: 2623.2944

e-mail; sosiodialektika@unwahas.ac.id doi; http://dx.doi.org/10.31942/sd.v6i2.5679
Efektifitas Pembelajaran Jarak Jauh Terhadap Kepuasan Proses Pembelajaran Di Prodi D3 Dan S1 Akuntansi Untidar

telah dilaksanakan mahasiswa S1 dan D3 Akuntansi di Fakultas Ekonomi Universitas Tidar dengan menggunakan berbagai media berlangsung cukup efektif. Mahasiswa bisa mengakses dan memahami materi pembelajaran Akuntansi yang telah disampaikan dosen melalui berbagai media online dan Elita dengan menggunakan gadgetnya. Interaksi antara dosen dan mahasiswa semakin ditingkatkan agar pemahaman mahasiswa dapat dilakukan dengan video dan chat materi di group telegram/whatsapp untuk menyelesaikan setiap tahap pembelajaran, namun mahasiswa menganggap biasa pada pemahaman materi dan proses evaluasi. Berdasarkan hasil penelitian tersebut, maka Universitas Tidar Fakultas Ekonomi Program Studi Akuntansi perlu meninjau kembali metode pembelajaran jarak jauh yang selama ini telah berlangsung dengan memberikan materi yang interaktif, inovatif dan mudah dipahami. Selain itu perlu memperkuat kemampuan digital baik dosen dan mahasiswa.

Kesimpulan yang dapat diambil dari penelitian ini adalah sebagai berikut:

1. Pembelajaran jarak jauh (daring) dapat digunakan untuk mencapai kepuasan dalam proses kegiatan belajar mengajar Prodi Akuntansi Untidar di masa pandemi Covid-19 saat ini melalui media pembelajaran yang digunakan dosen telah bervariasi atau beragam dan media pembelajaran telegram yang paling banyak digunakan atau sebesar 87,6\%. Kemudahan penerapan teknologi masa kini yang menjadikan media pembelajaran mudah diakses mahasiswa sebesar $55,9 \%$. Tingkat pemahaman mahasiswa terhadap materi pembelajaran, informasi dan pendalaman materi sebesar 52,4\%,

2. Pelaksanaan pembelajaran jarak jauh (daring) saat ini sudah efektif dalam mencapai tujuan proses kegiatan belajar mengajar Prodi Akuntansi Untidar di masa pandemi Covid-19 saat sebesar 39\%. Kepuasan mahasiswa terhadap pembelajaran jarak jauh yang sudah dilakukan selama masa pandemi pada Fakultas Ekonomi sebesar $40,2 \%$.

Saran dari peneliti bagi dosen, dosen dituntut bisa menyajikan materi 
Jurnal SOSIO DIALEKTIKA 6 (2) (2021)

P-ISSN: 2540.8941 e-ISSN: 2623.2944

e-mail; sosiodialektika@unwahas.ac.id doi; http://dx.doi.org/10.31942/sd.v6i2.5679
Efektifitas Pembelajaran Jarak Jauh Terhadap Kepuasan Proses Pembelajaran Di Prodi D3 Dan S1 Akuntansi Untidar

yang lebih interaktif dan mudah dipahami dengan mempertimbangkan kuantitas, kualitas dan waktu. Dengan memanfaatkan IPTEK, sarana dan prasarana yang tepat sesuai dengan materi yang akan diajarkan. Bentuk penugasan yang diberikan ke mahasiswa dirancang dengan memicu semangat mahasiswa untuk menyelesaikan tepat waktu dengan tingkat pemahaman yang baik serta tidak menjadi beban psikis dan rasa bosan. Dosen perlu berkreasi saat memberikan pemahaman materi kepada mahasiswa lebih inovatif dan karakterik di mata kuliah Akuntansi.

\section{DAFTAR PUSTAKA}

Abdillah, L. A. (2020). Online Learning Menggunakan Zoom Teleconference Work Form Home During COVID-19 Global Pandemic. Universitas Bina Darma. https://doi.org/10.6084/m9.figshare.12136611.v2

Deshwal, P., Trivedi, A., \& Himanshi, H. L. N. (2017). Online Learning Experience Scale Validation and Its Impact on Learners' Satisfaction. Procedia Computer Science, 112, 2455-2462. https://doi.org/10.1016/J.PROCS.2017.08.178

Direktorat Jenderal Pendidikan Tinggi. 2020. Panduan Penyelenggaraan Pembelajaran Semester Gasal 2020/2021 di Perguruan Tinggi. Jakarta

Isaac, O., Aldholay, A., Abdullah, Z., \& Ramayah, T. (2019). Online learning usage within Yemeni higher education: The role of compatibility and tasktechnology fit as mediating variables in the IS success model. Computers \& Education, 136 , $113-129$. https://doi.org/10.1016/J.COMPEDU.2019.02.012

Jafari Navimipour, N., \& Zareie, B. (2015). A model for assessing the impact of e-learning systems on employees' satisfaction. Computers in Human Behavior, 53, 475-485. https://doi.org/10.1016/J.CHB.2015.07.026

Kemendikbud. 2020. Pedoman Penyelenggaraan Belajar dari Rumah. www.kemdikbud.go.id. diakses pada 10 November 2020. 
Jurnal SOSIO DIALEKTIKA 6 (2) (2021)

P-ISSN: 2540.8941 e-ISSN: 2623.2944

e-mail; sosiodialektika@unwahas.ac.id doi; http://dx.doi.org/10.31942/sd.v6i2.5679
Efektifitas Pembelajaran Jarak Jauh Terhadap Kepuasan Proses Pembelajaran Di Prodi D3 Dan S1 Akuntansi Untidar

Latip, A. (2020). PERAN LITERASI TEKNOLOGI INFORMASI DAN KOMUNIKASI PADA PEMBELAJARAN JARAK JAUH DI MASA PANDEMI COVID-19. EduTeach: Jurnal Edukasi Dan Teknologi Pembelajaran, $1(2)$, $108-116$. https://doi.org/10.37859/EDUTEACH.V1I2.1956

Mustakim. (2020). EFEKTIVITAS PEMBELAJARAN DARING MENGGUNAKAN MEDIA ONLINE SELAMA PANDEMI COVID-19 PADA MATA PELAJARAN MATEMATIKA | Mustakim | Al asma: Journal of Islamic Education. $\quad$ Vol $2, \quad$ No. https://doi.org/https://doi.org/10.24252/asma.v2i1.13646

Nugroho, M. A., Setyorini, D., \& Novitasari, B. T. (2019). The role of satisfaction on perceived value and e-learning usage continuity relationship. Procedia $\begin{array}{llll}\text { Computer } & \text { Science, } & \text { 82-89. }\end{array}$ https://doi.org/10.1016/J.PROCS.2019.11.102

Pereira, F. A. D. M., Ramos, A. S. M., Gouvêa, M. A., \& Da Costa, M. F. (2015). Satisfaction and continuous use intention of e-learning service in Brazilian public organizations. Computers in Human Behavior, 46, 139-148. https://doi.org/10.1016/J.CHB.2015.01.016

Rahmawati, I. (2016). Pelatihan dan Pengembangan Pendidikan Jarak Jauh Berbasis Digital Class Platform Edmodo.

Restrepo, E. G. Y., Benavidez, C., \& Gutiérrez, H. (2012). The Challenge of Teaching to Create Accessible Learning Objects to Higher Education Lecturers. Procedia Computer Science, 14, 371-381. https://doi.org/10.1016/J.PROCS.2012.10.043

Rienties, B., \& Toetenel, L. (2016). The impact of learning design on student behaviour, satisfaction and performance: A cross-institutional comparison across 151 modules. Computers in Human Behavior, 60, 333-341. https://doi.org/10.1016/J.CHB.2016.02.074

Sanjaya, W. (2015). Perencanaan dan Desain Sistem Pembelajaran. Kencana. https://www.google.co.id/books/edition/Perencanaan_dan_Desain_Sistem_P 
Jurnal SOSIO DIALEKTIKA 6 (2) (2021)

P-ISSN: 2540.8941 e-ISSN: 2623.2944

e-mail; sosiodialektika@unwahas.ac.id doi; http://dx.doi.org/10.31942/sd.v6i2.5679
Efektifitas Pembelajaran Jarak Jauh Terhadap Kepuasan Proses Pembelajaran Di Prodi D3 Dan S1 Akuntansi Untidar

embelajar/Y9xDDwAAQBAJ?hl=id\&gbpv=1\&dq=rowntree+menggolongk an+bahan+ajar+menurut+sifatnya\&printsec=frontcover

Sidiq, R. (2019). PEMANFAATAN WHATSAPP GROUP DALAM PENGIMPLEMENTASIAN NILAI-NILAI KARAKTER PANCASILA PADA ERA DISRUPSI. Puteri Hijau: Jurnal Pendidikan Sejarah, 4(2), 145-154. https://doi.org/10.24114/PH.V4I2.16304

Smaldino, S. E., Lowther, D. L., Russell, J. W., \& Mims, C. L. (2014). Instructional Technology and Media for Learning With Video-enhanced Pearson Etext Access Card. Pearson College Div.

Sugiyono. (2018). Metode Peneiltian Kuantitatif, Kualitatif dan R\&D. In Alfabeta Bandung.

Veronica, D., \& Jaya, H. (2018). ANALISIS SISTEM PENGENDALIAN INTERN PENERIMAAN KAS DARI PIUTANG PADA PERUSAHAAN JASA EKSPEDISI DI PT. TRANS MUTLI CARGO. Measurement : Jurnal Akuntansi. https://doi.org/10.33373/measure.v12i1.1303

Wang, C., Hsu, H. C. K., Bonem, E. M., Moss, J. D., Yu, S., Nelson, D. B., \& Levesque-Bristol, C. (2019). Need satisfaction and need dissatisfaction: A comparative study of online and face-to-face learning contexts. Computers in Human Behavior, 95, 114-125. https://doi.org/10.1016/J.CHB.2019.01.034

YILMAZ, D., TANRIKULU, F., \& DIKMEN, Y. (2017). Research on Sleep Quality and the Factors Affecting the Sleep Quality of the Nursing Students. Current Health Sciences Journal, 43(1), 20. https://doi.org/10.12865/CHSJ.43.01.03 